K. TAKEYAMA, M.D.: RELATION BETWEEN PURE TONE

HEARING AND SPEECH HEARING

Part 1 Clinical Observation

\title{
純吾聽力と言語聴力との關係（臨休的觀察 其の一）
}

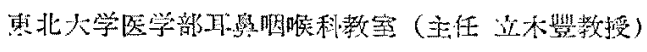 \\ 医学士 武山頁 次
}

\section{I. 緒 讋}

言語聴力を評洒寸る埸合，次の2つに分けて考え る事が最も妥当であると Davis 快述べている。艺 れは图1に示した様に明蹽庭曲線は臨床的に一つは 言語聴力損失 Hearing Loss for Speech で示さ れ，他の一つは言語升別損失 Discrimination Loss で示寸專が出来るからである。そこで著者は臨床的

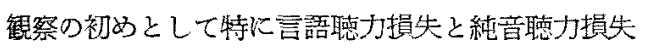
との関係破て考察し，又一部単音明暸度に就て研 究して見た。この言語聴力損失と純音聴力損失との 閣係纪就ては Fletcher, Carhart, Harris, Hughson

圆 1 Speechaudiogram

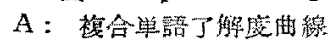

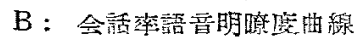

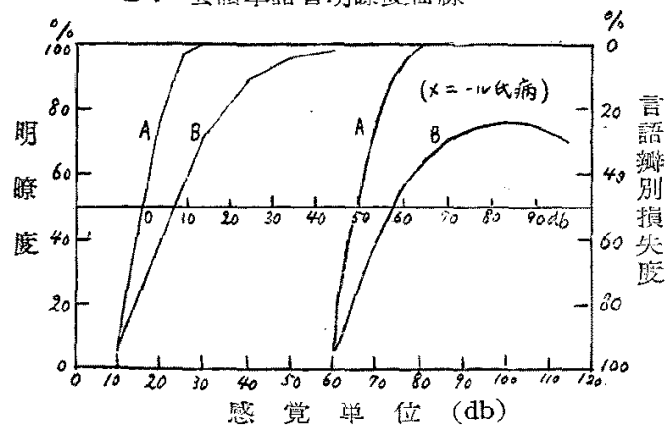

and Thampson, T. Palva, E. Hawkins and S.

S. Stevevens 等多数の研究が発表されているが， 未大国語に関しては全く発麦されていない。之は国 語代於ては言語德力損失测定に対する検查表がネた 確定しない事以电原团があると洘方られる。そこで

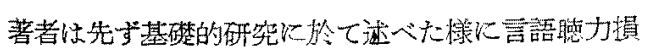
失測定表として䘸合単語表が最も妥当で市る事を知 つたので䙳らこの表を利用する事とした。

$8-25$
II. 富融方法

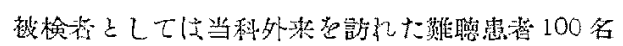

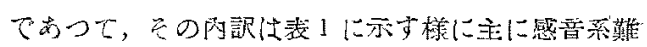

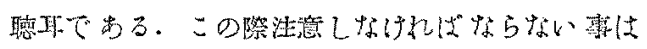
Hearing Loss for Speech z 純吾脐力損头 Pure-

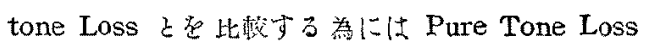

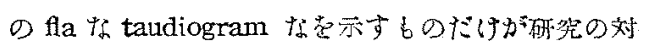
象々な行得ると云う事である。

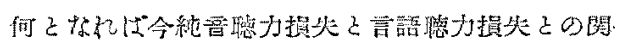

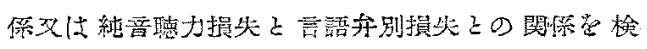

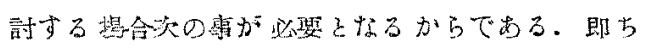

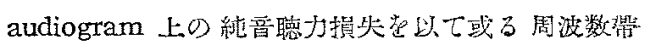

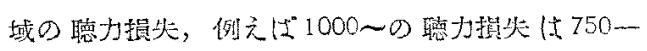
1500〜常域の喯力提夫把示さなければならない。

\section{表 1}

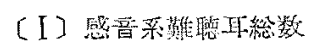

(1) $x=-ル$ 痛

(2) ストレプトーイシン中留

(3) 迷路㭽瑇

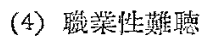

(5) 䫄部外偈

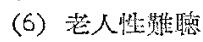

(7) ホマトール中臯

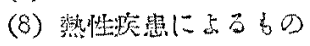

(9)垱腄境の疑

(10) 原因不明

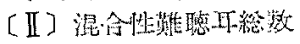

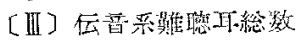

$$
\text { 合 院 }
$$

60 例

$7 "$

$4 "$

$5 \%$

$5 \%$

$2 "$

$2 \%$

$2 "$

$2 \%$

$2 \%$

$29 \%$

$25 \%$

$15 \%$

(100耳)

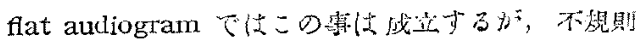

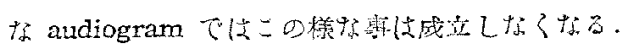
そこで琵者は成る可了 flatに近い audiogram 集放るころした。

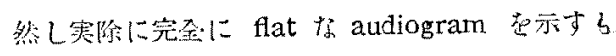


のはないのでむるか，Fletcher は per Octave 10

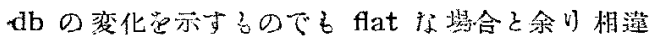

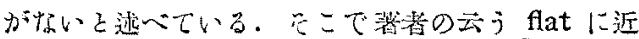

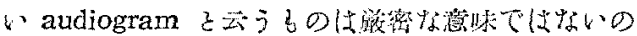
である。

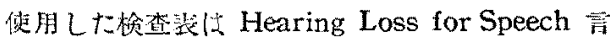

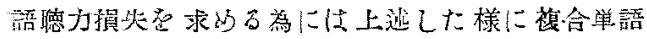

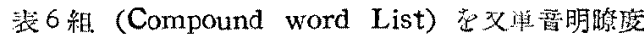

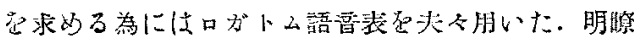

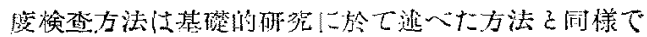
क了.

\section{III. 菑烈結果（附表参照）}

1) 純音聴力損失と言語聴力損失との関係

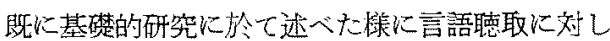
て重要な阔波数寡域は500，1000，2000 及び4000〜 蒂域で频り，更に speech の Loudness に対与る 重要度と云5点から見礼ば其の的で500，1000及び 2000〜带域が重要であると洘学りれるので著者は 500,1000 支び 2000〜於什る純音聴力損失の平均 值 (db) 娄以て純音德力損失 Pure Tone Loss と した. そして之と Hearing Loss for Speech と比 較して見た。その䑩果伝音系及び混合性難咕耳の場 合は図2に示した椂に Hearing Loss for Speech

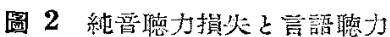
損失乙の閦续

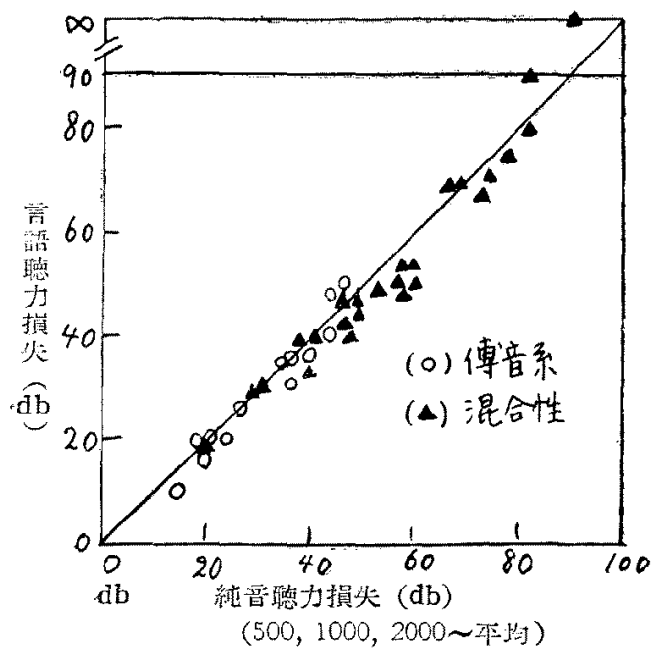

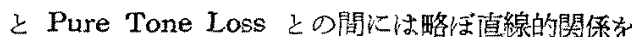

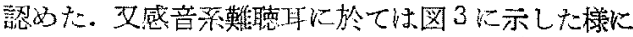
Pure Tone Loss 70〜80db 迄はそれ5相互の䦔以

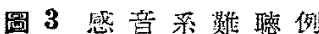

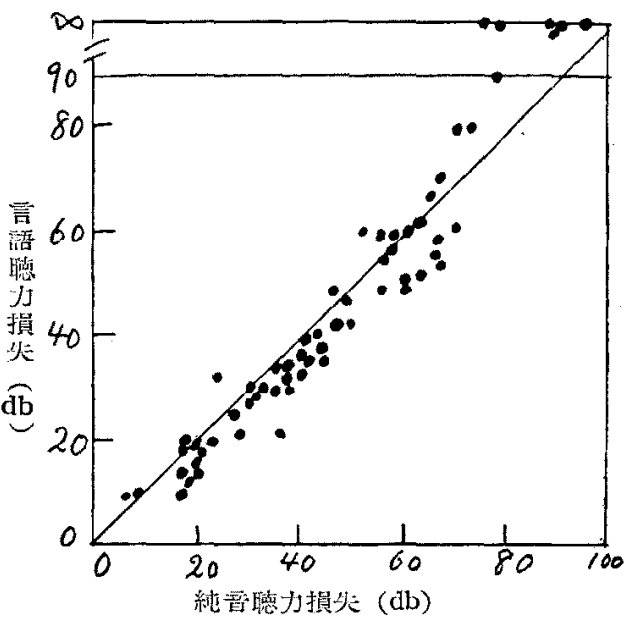

略ぼ直線的比例䦎係を䜑めた。但この堤合 $70 \sim 80$

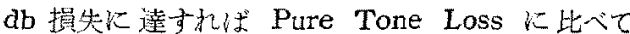
Hearing Loss for Speech が稍ミ大となり, 又時に

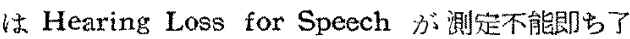
解度 $50 \%$ に達しなくなる例ぶ多くなる事を知つた。

2) 学音明瞭度に閣す万研究結果

国語音節（=話音）の構成は子音十母音の形で䋆

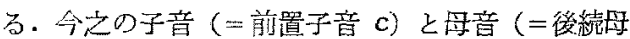

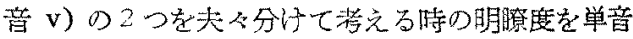
明嘹度 sound articulation と云与。今表沈示す様

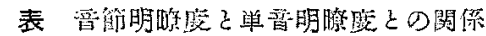
（三浦氏による）

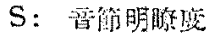

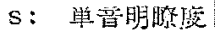

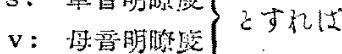

c：子湖脖照

$\mathrm{S}=0.95 \mathrm{c} \cdot \mathrm{v} \cdot+0.05 \mathrm{v}$

$\mathrm{s}=\frac{95 \mathrm{c}+100 \mathrm{v}}{195}$

$\mathrm{v} / \mathrm{c}=\lambda$

$\therefore S=\frac{0.05 \times 195}{100 \lambda+95} \lambda . S+$ $\frac{0.05 \times 195^{2}}{(100 \lambda+95)^{2}} \lambda . s^{2}$ 


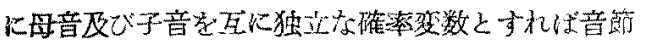
明膯度 (S) と等音明膯度 (s) とD間に $\mathbf{S}=\frac{0.05 \times 195}{100 \lambda+95} \lambda \cdot \mathrm{s}+\frac{0.95 \times 1952}{(100 \lambda+95)^{2}} \lambda \cdot \mathrm{s}^{2}$ なる理确 的関保が成立寸ると三浦氏日述べている。垃に $\lambda=$

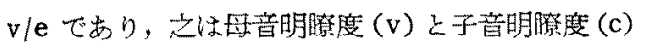
との比でする.困4に示した直線はその理諭的直線 であるが，正常耳の場合の矢験值は略ばこの直線に

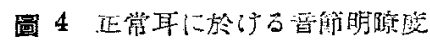

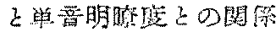

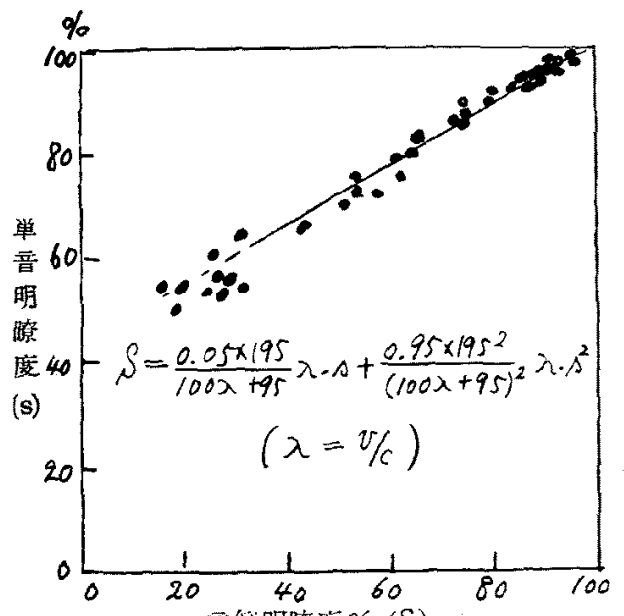

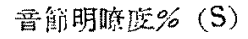

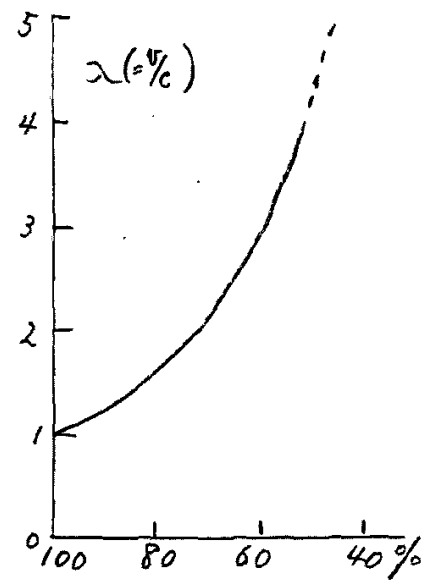

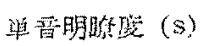

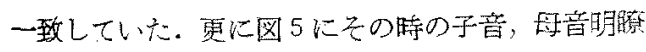

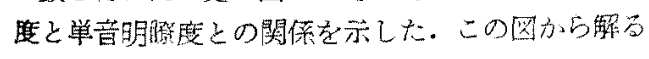
$8-27$

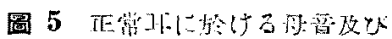
子音明期㛺

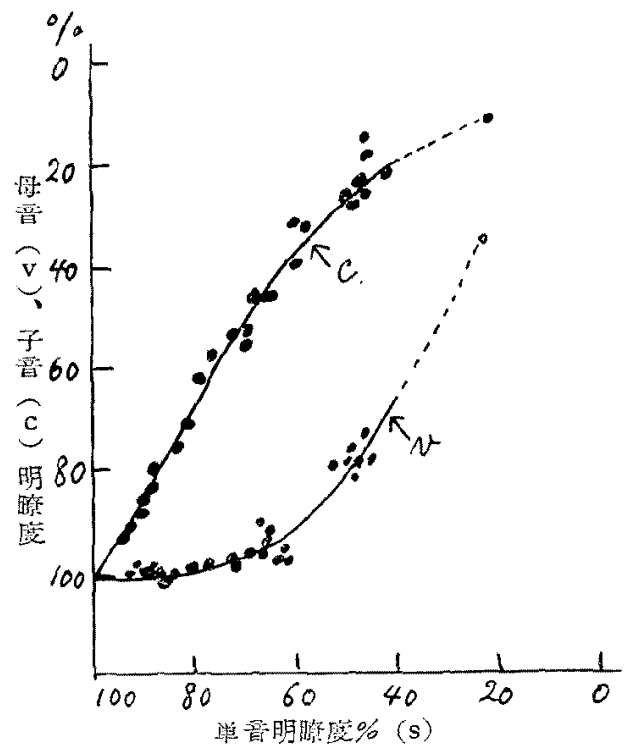

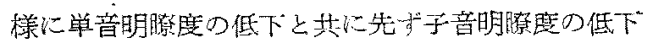

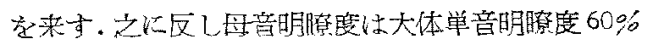

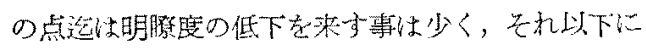

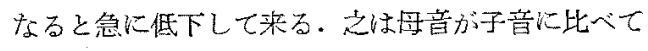

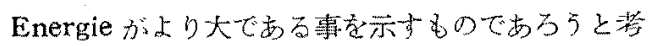

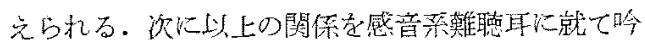

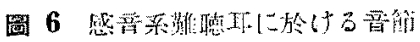

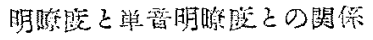

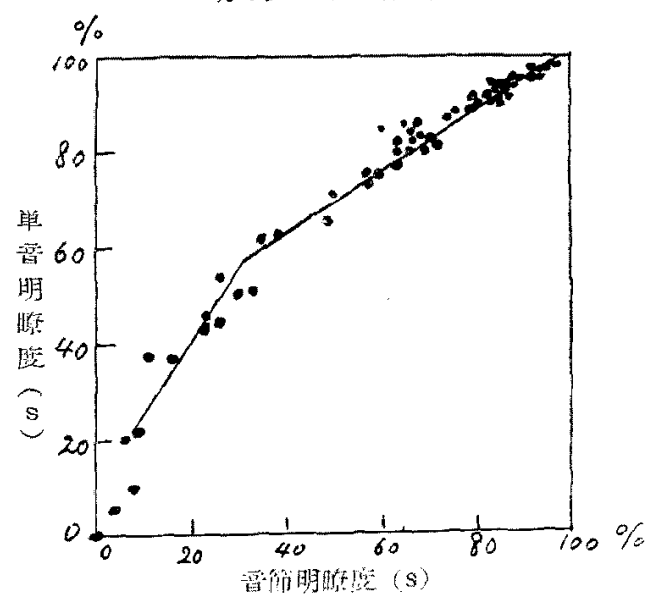


味して見た。その結果图 6 亿示す様に莦節明暸度

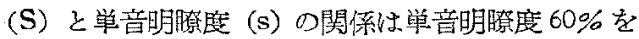
示す点迄は大体 normal な場合と同様な閣係を示 したが，それ以下では稍々念な傾きを示していた。 この事から感音积難聴耳に於ても或る程度迄性正營

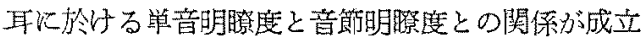

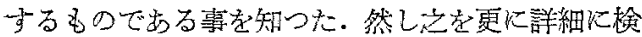

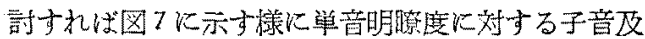

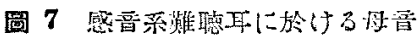

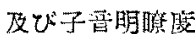

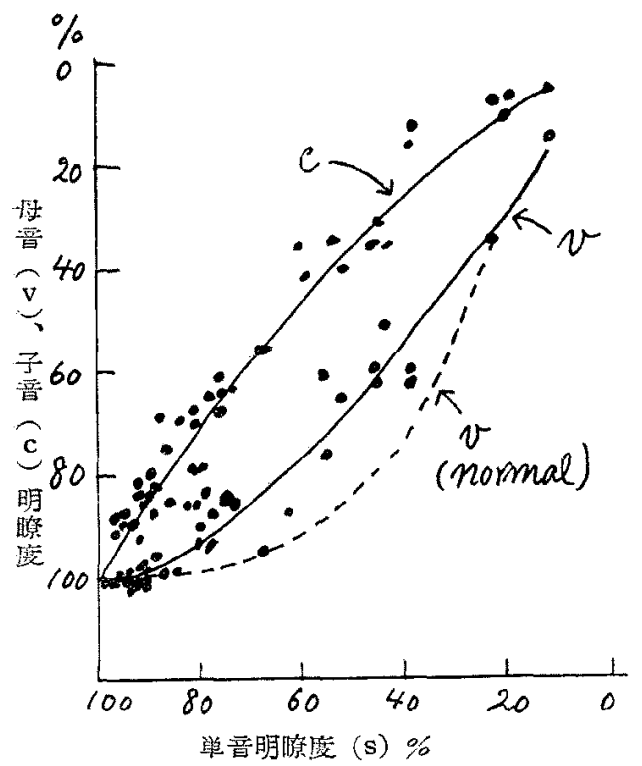

び田音明暸亩曲線の閣係は正常耳の場合と稍々異な つて来るものである事が解る，即ら耳音明膫度の低 下の仕ちが normal の㭙に比ベて大きくな西。之 そ反し子音明睹度の低下の 仕方は normal の暢合 と大差ない，此の事は感音系難聴耳儿於子る愦聴現

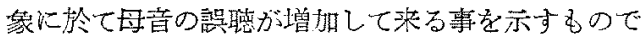
古をと考觉られる。

\section{IV. 考按}

1) 純音德力損失と言語聴力損失との䦭係：

之等相互の関係に就ては前述の情に多くの研究が 西加机ている。例えば Fletcher, Carhart, Hughson and Thompson, Harris, T. Palva 等注臨床的䚁 察を基として研究した結果 audiogram と Hearing Loss for Speech とは密接な関係を有する事孝認的 ている. そに区L Goldman は咡語枌查に於て余り 相関を諗めないと述べている。

著者の実験では Fletcher 等と同様にそれら相互 の間に同稳に密接な関係を諗めた。とこで著者は audiogram 3,5 Hearing Loss for Speech

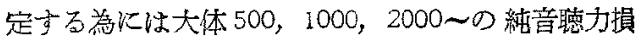
失の平均定为て現わ事が党当である事知つた。 次に感筸系難聴耳に於て 認められる Recruitment 現象は一体 Hearing Loss for Speech 飞影響与る ものであるか否かの点化て吟味することつする。 この点に関して Hawkins and S. Stevens は次の 凄な笑験を行つている・即す noise たよる masking によつて耳に一時的に Recruitment 琴象を成立せ

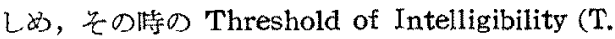

I.) そ Threshold of detectectability (T. D.) 同時に測定して見た. その結果 noise が上界してb T.I. と T.D. との閒の差は殆んど变化しなかつた 事加 5 Recruitment 現象に依る Threshold of Intelligibility への影響は沿んど無視し得るむので

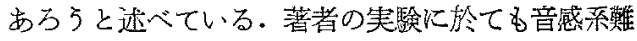
聴耳に於ける Pure Tone Loss と Hearing Loss for Speech 子の関倸が大体 70 80db 迄侩音系

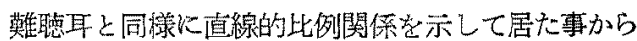
著者多亦 Hawkin and Stevens 等と同梯に Recruitment 現象は言語埴打損失に対しては余り影響 を与充ないも孝当。

2) 単音明瞭度に就て:

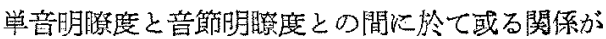
正常耳の場合成立するが，感音梁難聴耳に於ても大 驗此の関係が成立する・然しこの場合母音の誤聪が 多くなる事は一つの特徽であつて，之に反し子音の 語聴は余り变化しない.此の事は正常耳は伝音系灘

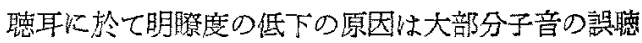
に由来するものであるが，感音添難聴の場合には子 音の外に母音の誤聴によつて明膫度低下を来亦事を 示するのであり，感音系難聴耳に於ける speech 
patternの破れ方の特徴に由来するるのであるろと 考完られる。

\section{V. 結隹}

先ず純音 500,1000 及び 2000〜の聴力損失の平均 々 Hearing Loss for Speech との閔係索検討して 胃た。元の結果伝音系難聴及び混合性難聴に於ては

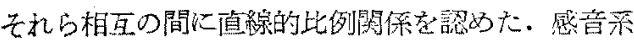

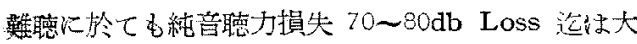

体との関係が成立するるのである事党知のた。この

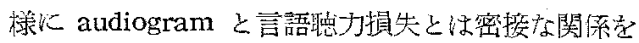
有するものである。

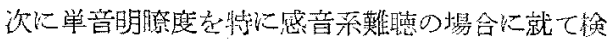
討して見た. その結果感音采難聴耳儿於子る明膫要 の低下の原因は子去部の愦聴むあるが，特徽として

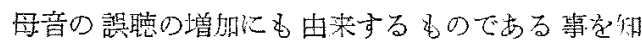
ot.

\section{K. TAKEYAMA, M.D. RELATION BETWEEN PURE TONE HEARING AND SPEECH HEARING \\ Part 2 Clinical Observation}

\section{純昔聴力と言語聴力との関係（臨床的観察 其の二）}

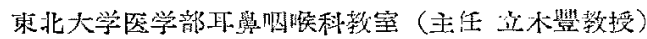

医学士 武紧其资

\section{I. 緒 言}

言語㯖力の詳拪は一つは言語噹了損失 Hearing Loss for Speech, 他の一つは誩語弁別損失 Discrimination Loss の二つによつて行い得るも のである事を述べ，前回は主に言語聴力損失と純音 聴力損失 Pure Tone Loss との関係に就て佁討し たので今度は特汇言語泋別損失と純音聴力損失との 関係に就て検討すること〉した。この言語弁別損失 性主に感音柔難聴耳に於て観察されるものであつ て，之が為に主に感音系嚾䏇耳蚞查の対像とし た，又之は伝音䒺難聴耳との間の大きな違いであ り，言語聴力検查に於て重要な䛧值を有するにか小 袄ず， Discrim Loss z Pure Tone Loss 20 関保に対する桧討は殆んど行われていない，唯外国 では臨床的に T. Palva 氏が迹べているに過ぎな い. 我国に於て子最近 Speech audiometry に関す る研究が盛儿に行われる椂になったが，来だをに関 する精密な検討は行われていない，然しこの問题は

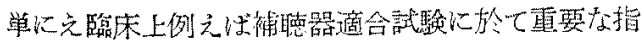
示を与克るのみならず，社会的邀応性を論ずる為に 毛欠く事が出来ない，面に言語聴力口機序に対する 8-29
解明以の一つの手がからとる成り得るすのと著者は 信じている。

\section{II. 雷羷方法}

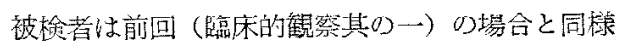

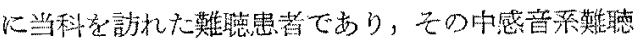
60 耳，混合性難聴 25 耳，伝音䒺難聴 15 耳であり， 総計 100 耳で禾つて，成る可く flat audiogam 宗するのだ付を検查の対象とした。この場合感音系

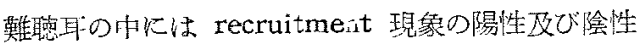

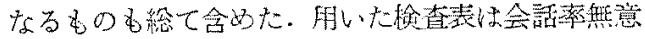
音節表 (50 語音表) 3 枚，及びロガトム語音表であ る。故查方法としては先ず複合単語了解度 $50 \%$ を 示す点を测定した (即り Hearing Loss for Speech

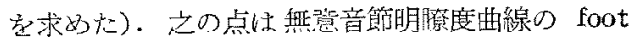
point 炡相当するすのであるから，この音の强さの level 飞於て明膫度を求め，次火 $20 \mathrm{db}$ 五つ上昇し 2 回測定した。即ち合計了点を测定する静によつて 明膫度曲線を求めることつした。この埸合感音系㩲 聴耳て怔更记 most Comfortable Loudness 老示

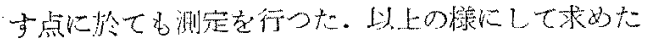

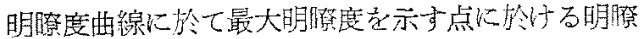

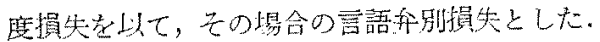

